\title{
Examining the corporate social responsibility orientation in developing countries: an empirical investigation of the Carroll's CSR pyramid
}

\author{
Ike C. Ehie \\ Management Department, \\ Kansas State University, \\ 1A Calvin Hall, \\ Manhattan, KS 66506, USA \\ Email: iehie@ksu.edu
}

\begin{abstract}
We investigate the seminal Carroll's corporate social responsibility (CSR) hierarchy using a sample from Nigerian companies. Carroll (1991) outlined four major components of CSR in a cumulative framework with economic responsibilities at the base and philanthropic responsibilities at the top of the pyramid with the legal and ethical components in between. The relevance of Carroll's CSR pyramid in the African context has been questioned and the need for an empirical study on the appropriateness of the CSR pyramid in Africa has been called for. This study is in response to this call to empirically test the relevance of the Carroll's CSR pyramid in the sub-Saharan Africa region. The study also tests the proposition that CSR is viewed through the lens of philanthropy in Africa. The findings empirically validate Visser's (2006) proposition that the philanthropic component weighs heavier than both the legal and ethical components of the CSR pyramid. The results provide a basis for the reliance on corporate philanthropy and guide CSR managers in sub-Saharan Africa in understanding the orientation that would lead to a more effective CSR implementation.
\end{abstract}

Keywords: CSR orientation; CSR pyramid; corporate philanthropy; sub-Saharan Africa; SSA; developing country.

Reference to this paper should be made as follows: Ehie, I.C. (2016) 'Examining the corporate social responsibility orientation in developing countries: an empirical investigation of the Carroll's CSR pyramid', Int. J. Business Governance and Ethics, Vol. 11, No. 1, pp.1-20.

Biographical notes: Ike C. Ehie is a Professor of Operations and Supply Chain Management at Kansas State University. He received his $\mathrm{PhD}$ in Engineering Management from Missouri University of Science and Technology (MOST) with emphasis in operations management. He has published extensively in manufacturing strategy and operations management. His papers have been published in outlets such as Interfaces, Omega, European Journal of Operational Research and International Journal of Operations and Production Management. He was the principal investigator of a USAID grant aimed at improving the quality of the business administration curricular at the University of Lagos, Lagos, Nigeria. 


\section{Introduction}

In the wake of the growing interest in corporate social responsibility (CSR), especially in sub-Saharan Africa (SSA), this study investigates the perception and understanding of CSR orientation among a sample of major private companies in Nigeria. Nigeria accounts for about $21 \%$ of the SSA gross domestic product (GDP) and represents over $20 \%$ of the regional population of SSA (World Bank, 2014). SSA is now the second fastest growing region in the world, second to the emerging Asian countries (IMF, 2014). SSA continues to be the source of cheap raw material for many multinational companies that operate in the region (Crane et al., 2008). Chinese firms have launched a global quest for access to raw materials and markets in Central Asia, Latin America, East Asia, and SSA (Zafar, 2007). This reality confirms the major reason for the recent surge in CSR in the developing economies. There has been the realisation that strategic CSR policies in SSA are the sine-qua non for sustainable development. The German government commissioned a survey through its Center for Cooperation with Private Sectors (CCPS) to understand the factors that inhibit and promote CSR in SSA. The Center recently issued a report titled Shaping Corporate Social Responsibility in Sub-Saharan Africa: Guidance Notes from a Mapping Survey (GIZ, 2012). The major finding of the report is to intensify the impact and scope of CSR initiatives through synergistic networking, shared learning, and capacity building (GIZ, 2012). Many of the points raised in the GIZ report call for businesses to not only share their wealth with the countries where they do business, but also to assist in promoting sustainable economic development and good governance. Any business with a desire to create lasting value will have to invest in the improvement of the societal conditions in which it is embedded and engage and collaborate with the institutional actors that contribute to the improvement of the macroeconomic conditions at a national level (GIZ, 2012). The GIZ study focused on six countries in SSA, except Nigeria. As one of the fastest growing economy in Africa, it is worthwhile to investigate the extent to which Nigerian companies practice CSR and the underlying framework for CSR implementation.

Nigeria has a population of about 170 million, most of whom are in the adult-working age (18-64 years). Nigeria has been cited as the fastest growing economy in Africa with an average growth rate of 7\%, surpassing South Africa (The Economist, 2014). However, CSR is practiced by a negligible number of organisations in Nigeria. A paradigm shift must take place that will propel CSR implementation from an 'obligation' mindset to a strategic mindset (Egbas, 2009). In a majority of the cases, CSR is yet to be adopted as a strategic business initiative. Only in a few instances have large corporations like Nestle, Unilever, MTN, and some of the major banks (Zenith, GTB, etc.) adopted CSR as a strategic initiative in their businesses. The financial and telecommunication industries by far have the highest penetration in adopting CSR as a holistic business initiative (Egbas, 2009). Although large sums of money have been spent on CSR practices in Nigeria, the CSR projects have produced minimal impact and unsustainable results. One reason cited is the fragmented manner with which the CSR programs were being developed and implemented. In an exploratory study of stakeholder expectations of CSR in Nigeria, the author conclude that while there is a flurry of CSR activities with high media visibility by the corporate affairs and the CSR departments of various organisations, there continues to be a disconnect between the beneficiaries and stakeholders who seem not to understand the true essence of CSR (Oku et al., 2009). The net result is that CSR projects are designed as a publicity showcase, rather than projects designed to meet a strategic need. 
This fragmented approach to CSR may be attributed to the lack of a general framework for CSR implementation in Nigeria. Companies need to develop more synergistic relationships between themselves and their stakeholder (employees, community, customer, shareholders, etc.) in order to realise the full benefit of CSR. Corporations in Nigeria need to develop a clear sense of social engagement that would leverage their economic power to foster greater social power (Egbas, 2009). Only after this is accomplished can CSR become a veritable vehicle for sustainable development. In addition, communication of CSR initiatives have been secretly guarded by companies in Nigeria not willing to share information. CSR reporting should set out how the organisation plans to hold itself accountable for progress.

Numerous debates have emerged regarding the precise definition of CSR. We adopt the definition proposed by the World Business Council for Sustainable Development that defines CSR as the "continuing commitment by business to behave ethically and contribute to economic development while improving the quality of life of the workforce and their families as well as the local community and society at large" (WBCSD, 2005). Most approaches to CSR adopted in developing economies are borrowed from the western world where the stages of development and the prevailing circumstances are dissimilar. The different environmental conditions have not only shape the nature of obligations that are required of businesses in developing countries, but also affect the success or failure of business initiatives to meet social obligations (Idemudia, 2011). As argued fervently by Travis (1982), it is not that the environment of developing countries has been ineffective in serving the needs of its people, rather, it is that the environment is not like that of the USA where most of the prevailing CSR models are based. Against this backdrop, this study is undertaken to assess the relevance and applicability of the Carroll's hierarchical CSR model in a SSA context. Furthermore, the study strives to establish the dominant framework for CSR implementation in Nigeria. The next section explores the literature on CSR as it pertains to developing countries. This is followed by an investigation of CSR theories that have been postulated to aid the understanding of CSR implementation. We then reviewed studies that focused on Carroll's CSR pyramid. This provides the entry into the main object of our study, which is to test the relevance of CSR pyramid and the role of philanthropy in CSR adoption in Nigeria. The methodology of the study along with the analytical approach is presented with results and analyses discussed. The paper concludes with major contributions, limitations and areas for further studies.

\section{Literature review}

The debate over the role of CSR in corporate well-being continues to evolve with both sides of the debate holding to their respective positions. Opponents of CSR argue that the role of business is to use its scarce resources and engage in activities designed to increase its profits so long as it stays within the rules of the game (Friedman, 1970). Protégés of Freidman argue that CSR weakens the firm's competitive position, and dilutes the efforts of managers who are supposed to focus on economic productivity (Davis, 1973). In an earlier paper, titled 'The danger of social responsibility', Levitt (1958) commented that "its guilt-driven urge" has caused the modern corporation to reshape, not simply the economic but also institutional, social, cultural and political topology of society. Likewise, proponents of CSR have argued strongly in favour of the social values of CSR 
and its linkage with business performance. Creative capitalism encourages companies to stretch the reach of market forces so that more people can make profit by doing work that eases the world inequalities. Porter and Kramer (2011) in redefining business competitiveness argue that value creation needs to be re-focused into integrating social initiatives and philanthropic responsibilities into the existing profit-generating strategy. Building businesses aimed at the bottom of the economic pyramid, not only provides competitive advantages for companies moving into the twenty first century but also holds greater promise for a more stable and less dangerous world (Prahalad and Hammond, 2002). The case of 'enlightened self-interest' has been advocated as a justification for CSR in organisations. Both business and the civil society as a whole will benefit from socially responsible behaviour. As clearly stated by Fashola (2011) in his Lagos Tennant Bill signed into law, he affirmed that "a society that cannot protect the underprivileged cannot protect the privileged". A better society produces a more civilised environment where people feel less threatened. To dismiss social responsibility is to allow corporate behaviour to drop to the lowest common denominator (Mintzberg, 1983). These arguments borrow from the popular institutional theory which posits that policy-making emphasises the formal and legal aspects of government structures (Kraft and Furlong, 2007). Campbell (2007) argues that basic economic factors such as general financial conditions of a firm, the health of the economy, and the level of competition a company faces are all likely to affect the degree to which the company acts in a socially responsible manner. The author further made the case that the relationships between economic conditions and socially responsible corporate behaviour are mediated by several institutional factors such as public and private regulations, the presence of non-governmental and other independent organisations that monitor corporate behaviours, and institutional norms and values regarding appropriate corporate behaviours. Galaskiewicz (1991) found that corporations tend to act in socially responsible ways if normative or cultural institutions are in place that offer the proper set of incentives for such behaviour. Corporate actors that belong to business or professional associations that promote charitable giving are more likely to engage in philanthropic activities themselves.

Besides social performance that can be achieved through CSR, studies have shown direct link between CSR and financial performance of firms. Waddock and Graves (1997) found through regression analyses that an increase in corporate financial performance was associated positively with an increase in CSR. Bowman and Haire (1975) found that those firms with CSR practices performed significantly better than those with none ( $14.7 \%$ returns on equity vs. $10.2 \%$ over the preceding five years). Generally, the business case for CSR is being made by documenting and illustrating that CSR has a positive economic impact on firm financial performance (Carroll and Shabana, 2010). In what has been termed 'responsible supply chain' (Lehmacher and Pearse, 2015), leading companies are now looking for ways to adopt the 'triple supply chain advantage' in which they achieve their profitability target while benefiting the environment and society at large. Prahalad and Hammond (2002) in analysing the Indian experience emphasised the need for mind-set changes for converting the poor and underprivileged (bottom of the pyramid - BOP) into active consumers. The authors advocate that western multinational corporations (MNCs) through their responsible social behaviour can raise the standard of living in poverty-stricken part of the world by enabling billions of potential consumers to participate fully in the global marketplace while at the same time enabling the MNCs' to unleash untapped market potential that 
abounds in these developing economies. This creates a win-win situation for both the poor and rich communities and a distinct competitive advantage for the MNCs. Judging from the foregoing, the benefits of CSR tend to outweigh its cost.

Companies are under growing pressure to embrace CSR programs, in part due to emerging public awareness and standards of social contract (i.e. United Nations Global Compact, ISO 14000), and due to the proliferation of independent evaluations and rankings that make social performance more transparent. Unfortunately, the role and awareness of CSR is still under-developed, especially in SSA. Whereas most developed countries have advanced in CSR by looking holistically and strategically at the concept, countries in SSA region consider CSR as being primarily philanthropic (Kolk and Lenfant, 2010; Amaeshi et al., 2007; Idemudia, 2011; Wheeler et al., 2002; Boele et al., 2001). These studies show that both local and multinational companies in developing countries continue to view their CSR commitments through the lens of philanthropy. This makes the level of CSR engagement to be tactical at best because the efforts, which largely involve spending money in the community to garner positive public relations and customer goodwill, are often not strategically aligned with the overall missions of the companies. To be effective, CSR must align with the core business mission and be linked with the competitive priorities of the firm (McElhaney, 2008). In order to develop a strategic posture on CSR, one must adopt an effective framework upon which to build the CSR initiatives. Such a framework does not currently exist given the fragmented nature with which CSR in being implemented in Nigeria.

Developing countries are characterised by various features that can offer considerable scope for the exercise of CSR. These include low standards of living, high corruption, oppressive regimes with low regard for human rights, poor provision for health care and education, as well as low levels of per capita income and foreign direct investment (Crane et al., 2008). The campaign against Shell Oil Company for their operations in the Niger Delta of Nigeria has, among other things raised greater awareness on responsible corporate behaviour, especially among the multinational companies (Ite, 2004). The litmus test is for MNCs in developing countries to conduct their business operations similar to what would be considered as being socially responsible in their home country (Crane et al., 2008). CSR should be viewed not just as aid but as a vehicle that fosters both economic and social development in these regions. While research studies have helped obtain more insight into CSR, evidence shows that Africa is much less well researched than other regions (Kolk and Lenfant, 2013). This partly reinforces the inquiry into this area of study.

\subsection{CSR frameworks}

Several models have been advanced as legitimate framework for implementing CSR. CSR is generally understood to be the way a company achieves a balance or integration of economic, environmental, and social imperatives while addressing shareholders and stakeholders expectations (Olokode, 2008). Carroll (1991) proposed the four-component hierarchical model on CSR that begins with the economic component at the base and progresses to legal, ethical and philanthropic component at the top of the hierarchy. The Carroll's CSR pyramid is both pragmatic and realistic, taking into account the altruistic characteristics of a firm without abdicating businesses' duty to meet the economic responsibility of the firm (Crane et al., 2008). Although this framework has found much applicability in the western world, the appropriateness of this framework in Africa has 
been called into question (Visser, 2006). Matten and Moon (2008) proposed the implicit and explicit CSR as a conceptual framework for understanding CSR. The explicit CSR refers to the voluntary programs and strategies that combine social and business values, whereas the implicit CSR looks at values, norms and rules which inherently require corporations to address stakeholders' issues. McElhaney (2008) proposed a CSR maturity model that takes companies from the initial philanthropic phase, often involving grants and donations, through the transactional phase and finally to the integrative phase where companies view CSR as a strategic initiative in meeting the company's overall mission. Looking at this model, the fact that some companies focus heavily on the philanthropic phase implies that they are at the beginning stages of their CSR development. Pirsch et al. (2007) adopts institutional theory in classifying CSR programs under institutional and promotional programs. Institutional programs are most effective at increasing customer loyalty, enhancing attitude toward the company, and decreasing consumer skepticism. Promotional CSR programs, on the other hand are geared toward increasing the customer's willingness to purchase the company's products. Several authors have espoused the stakeholder theory in relation to CSR (Freeman, 1984; Mitchell et al., 1997). Stakeholder theory examines whether and why corporations attend to the interests of stakeholders along with their own immediate corporate interests (Campbell, 2007). The theory is closely related to the issue of CSR to the extent that it defines appropriate and inappropriate corporate conducts in terms of how corporations act in relation with their stakeholders (Driver and Thompson, 2002). The understanding of a company's stakeholder is central to CSR implementation. Stakeholders form the connection between the aims and ambitions of an organisation and expectation of society (Moan et al., 2009). Stakeholder theory emphasises that an organisation's survival and success is based on its ability to generate sufficient wealth, value, and satisfaction for its stakeholders (Clarkson, 1995). Post et al. (1996) defined as primary stakeholders those entities whose direct relationships with the organisation are central to realising the mission of producing goods and services that meet the needs of the customers. Secondary stakeholders on the other hand include social and political players who support the mission of the organisation by providing tacit approval of the organisation's activities, thereby making them acceptable and reputable in the eyes of the society. Such secondary stakeholders which constitute the stronghold of most organisations in SSA include local communities, governments, civic and non-governmental organisations. Vlachos (2010) shows how stakeholder CSR perception favourably influence business performance, especially through company innovativeness. Moan et al. (2009) developed a four-stage CSR design and implementation framework that span into nine steps. The steps range from raising CSR awareness, establishing the vision for CSR, assessing current practices and developing CSR integrated strategies to implementing and institutionalising CSR across the organisation. Garriga and Meles (2004) in mapping the territory of CSR outlined four distinct theories, namely instrumental, political, integrative and ethical theories. The authors recommend the need to develop an overarching theory on business and society relationship that will incorporate all four theories. Quazi and O'Brien (2000) developed a two-dimensional CSR framework (span of CSR and cost/benefit of business social commitment) that accounts for diverse environments with different socio-cultural and market settings. The model, which was empirically tested and validated using data from two distinct cultures - Australia and Bangladesh, reiterates that society at large is more responsive to sociocultural than economic issues. Majority of these frameworks were developed using experiences drawn from the West and these models may not be 
appropriate in their entirety when applied in a developing country context. Of all the models listed, the one that has received the greatest attention in the literature and has been universally applied is the Carroll's CSR pyramid.

\subsection{The CSR pyramid}

Carroll (1991) proposed the CSR pyramid which posits four basic components of CSR economic (producing goods and services for profit), legal (obeying the law while attempting to make profit), ethical (behaving in accordance with societal norms embodies in the law), and philanthropic (going beyond the profit motives to act as a good corporate citizen and living up to the societal expectations). Although philanthropy was viewed as a highly desirable and prized component of CSR, it is seen as being less important than the other three components of CSR (Kakabadse et al., 2005). Many studies have provided empirical evidence on general perception and understanding of CSR based on Carroll's pyramid of CSR framework (Pinkston and Carroll, 1996; Ibrahim et al., 2003; Kusku and Zarkada-Fraser, 2004; Ibrahim and Parsa, 2005; Peterson, 2004; Smith et al., 2004; Smith et al., 2001; Maignan and Ferrell, 2003). Edmondson and Carroll (1999) applied the Aupperle's (1984) forced-choice instrument to black business owners and found that the philanthropic components is weighted higher than previously reported. Likewise, female show higher preference for philanthropic CSR than their male counterpart. Ibrahim and Angelidis (1984) found significant differences in CSR orientation between male and female. They found that female directors exhibit a stronger orientation toward the philanthropic component of CSR than their male counterparts. Although the respondents in various studies placed more emphasis on the economic component, the non-economic components taken together score a greater weight than the economic component. The non-economic components combined have averaged between 60 and $65 \%$ of firms' total responsibility on CSR (Burton et al., 2000). A summary of these studies is presented in Table 1. In general, these studies support the CSR pyramid framework that gives the highest weigh to the economic dimension and the least weight to the philanthropic (discretional) dimension.

Table 1 Summary of results showing the ranking of CSR pyramid

\begin{tabular}{lcccc}
\hline Study & Economic & Legal & Ethical & Philanthropic \\
\hline Aupperle et al. (1985) & 3.50 & 2.54 & 2.22 & 1.30 \\
Ibrahim and Angelidis (1995) & 3.77 & 2.50 & 2.08 & 1.31 \\
Pinkston and Carroll (1996) & 3.28 & 3.07 & 2.45 & 1.15 \\
Edmondson and Carroll (1999) & 3.16 & 2.12 & 2.19 & 2.04 \\
Smith et al. (2001) & 2.96 & 2.63 & 2.35 & 1.63 \\
Ibrahim et al. (2003) & 3.31 & 2.65 & 2.19 & 1.73 \\
Angelidis and Ibrahim (2004) & 2.55 & 2.71 & 2.67 & 1.86 \\
Ibrahim and Parsa (2005) & 3.69 & 2.87 & 2.02 & 1.23 \\
Dusuki and Yusof (2008) & 2.39 & 2.25 & 2.27 & 2.17 \\
\hline
\end{tabular}

Although the pyramid model has received wide recognition, it is not without its critics. Several authors have suggested that the model is less suitable in national and contextual circumstances outside the USA (Maignan, 2001; Visser, 2006). The general approach to 
CSR in Africa continues to be fragmented with different models applied in different situations (Visser, 2006). The need to study the prevailing framework on CSR implementation in SSA is therefore warranted. We investigate empirically the adequacy and relevance of the Carroll's pyramid on CSR practices in SSA with reference to a sample of CSR managers in Nigeria.

\section{Research objectives}

This study assesses the general perception of CSR practices in Nigeria. Specifically, the study investigates the orientation of CSR using Carroll's (1991) pyramid of CSR framework. Studies have shown that different countries have different perception and understanding of CSR concept (Ibrahim and Parsa, 2005; Kusku and Zarkada-Fraser, 2004; Maignan and Ferrell, 2003). This might be due to cultural or religious factors that influence the perception of the CSR conceptualisation. In general, the literature on CSR in SSA is fairly underdeveloped and this study is an attempt to add to this body of knowledge. The key research question is whether Nigerian CSR managers view the hierarchy of the four-component CSR framework as being reflective of their views on CSR. Where they do not agree with the hierarchy, what would be the appropriate hierarchy that reflects their views on CSR adoption in Nigeria? Furthermore, the study investigates the extent to which CSR in SSA is viewed from a philanthropic perspective. To that end, the following research questions are established.

The major objective of this research is to provide knowledge regarding the generally accepted framework for the adoption of CSR programs in Nigeria business environment in particular, and SSA in general. Specifically, the objectives of this research are to

1 understand the underlining framework for implementing CSR in a developing country such as Nigeria using the Carroll's framework

2 test the applicability of the cumulative model advanced by Carroll (1999)

3 to test the proposition that CSR in Africa is viewed as being philanthropic.

Given these objectives, the paper will attempt to put forward a general framework for the adoption of CSR in Nigeria.

There is a strong argument that CSR in developing countries is most directly shaped by the socio-economic environment in which the firms operate (Dartey-Baah and Amponsah-Tawiah, 2011). Amaeshi et al. (2006) argue that CSR in Nigeria focuses on addressing the socio-economic challenges that include poverty alleviation, healthcare needs, infrastructure development, educational opportunities, corruption and good governance. These stand in contrast to CSR perception in the West that gives priority to consumer protectionism, fair trade, green revolution, climate change, and socially responsible investments. Multinational companies in developing countries assist in shaping the socio-economic and political landscape in order to create an operating environment which is conducive for businesses. These companies are beginning to realise that they need social license in order to operate successfully in the communities in which they conduct their businesses. CSR is therefore viewed as the relationships corporations develop with their constituents to align their values with societal expectations. Warfield- 
Coppock (1995) defines two types of organisations, namely - Eurocentric organisations based on materialism, hierarchical control, bottom-line profit and competition; and the Afrocentric organisations that are based on harmony, spirituality, and humanistic principles that seek to support members and people over profit. According to this theory, societies that are Afrocentric tend to favour philanthropic responsibility more than the Eurocentric-based societies. The Eurocentric organisation is derived predominantly from western and European tradition of capitalism, whereas the Afrocentric organisation has elements from humanistic principles found in most African cultures (Daniels, 2012). Philanthropy generally gets a higher priority as a manifestation of CSR in Africa (Visser, 2006). Companies realise that they cannot succeed in a failed society, and philanthropy is seen as the most direct way to improve the prospects of the communities in which business operates. Visser (2006) outlined three reasons why philanthropic CSR is very crucial in the African context. The first is that the socio-economic challenges faced by most African communities are so great that philanthropic CSR seems to be more appropriate. Companies become vulnerable if they are perceived as not giving back to the communities from where they operate their businesses. A case in point is the negative publicity regarding Shell Oil Nigeria with the way they mishandled both the humanitarian and environmental issues in the Niger-Delta region of Nigeria. Secondly, because of the reliance on foreign aid, there is an ingrained culture of philanthropy in Africa. This is demonstrated by the active role of the Chinese government in building infrastructural projects in a host of African countries, including Nigeria. Thirdly, the CSR concept is still underdeveloped in Africa and because of the lack of a strategic and integrative approach to CSR, there is a greater tendency to equate CSR to philanthropy. Subsequently, we test the following hypothesis:

$\mathrm{H}_{1} \quad$ The practice of CSR in Nigeria is viewed from the lens of corporate philanthropy.

Businesses have their primary responsibility to their shareholders. In order to build a sustainable CSR program, companies must ensure that they stand on a sound financial footing. Carroll's economic component provides the economic base upon which the organisation is founded. In today's global competitive market, business survivability is predicated on its ability create wealth and return shareholders' value. Therefore, having the economic component at the base of the pyramid holds a universal truth. The legal dimension which depicts business ability to comply with the laws and regulations of the land while pursuing its profit motive might vary depending on established laws of the land. A developing country that is grappling with established laws and regulations to guide its business practices may view the legal component differently. The third component is the ethical dimension which embraces values and norms. This is probably the most difficult to deal with, given the increased level of corruption in most developing countries. In SSA, 92\% of the countries scored below 50 out of a 100 on the corruption perception index (Transparency International, 2014). The fourth component is the philanthropic dimension which demands that businesses operate as good corporate citizen by giving back to the community and the environment which they serve. Carroll's background as a researcher from the West gives credence to the basics of the model, especially when applied to the western countries. The western-based CSR classification which is based on a Eurocentric culture may not be applicable in its entirety to an African context. The African context, which can best be described as an Afrocentric culture, favours a communal team orientation and support for group, which aligns better with the 
philanthropic mindset. To explore this proposition empirically, we test the following research hypothesis:

$\mathrm{H}_{2} \quad$ Although CSR practices in Nigeria confirm the presence of the four components of the Carroll's model - economic, legal, ethical and philanthropic, they do not conform to the hierarchical progression of the Carroll's pyramid model.

\section{Methodology}

The study adopts the instrument used by Tan and Komaran (2006) in testing the Carroll's (1991) CSR framework in Singapore, augmented by items used by Aupperle (1984). The final instrument has eights items in each component, four items taken respectively from Tan and Komaran (2006) and Aupperle (1984). The original survey, developed by Aupperle (1984), has been widely adopted in the literature, specifically to test the Carroll conceptualisation of CSR (Ibrahim and Angelidis, 1995; Pinkston and Carroll, 1996; Edmondson and Carroll, 1999; Smith et al., 2001, 2004; Ibrahim et al., 2003; Marz et al., 2003; Angelidis and Ibrahim, 2004; Ibrahim and Parsa, 2005). The instrument, whose design was guided by the definitions of each of the CSR components, covers all CSR dimensions in the Carroll CSR pyramid construct. The instrument contains items under each component that attempt to capture the essence of the respondents' orientation on CSR practices (see Appendix). We adopted the normative Likert scale for its ease of use, especially with managers in developing countries. Respondents were asked to measure their perceptions of CSR on a five-point Likert scale with ' 1 ' for 'totally disagree' and ' 5 ' for 'fully agree'. Demographic data on age, gender, education level, and length of working experience, job title/position and nature of company/organisation were obtained from the respondents.

\subsection{Demographics of respondents}

Whereas previous studies (Tan and Komaran, 2006; Dusuki and Yusof, 2008) used students as proxies for stakeholder groups of customers and employees to empirically test industry perception of the Carroll's CSR framework, this study used a group of CSR professionals that were assembled for a CSR roundtable organised by the Lagos Business School, Pan-Atlantic University. The roundtable was funded by Etisalat, a major telecommunications company in Nigeria. Altogether, there were 53 managers that completed the survey as shown in Table 2 . About $23 \%$ of the respondents came from the telecommunications industry which is a booming industry since the advent of the mobile phones. Nine companies (16.28\%) respectively, are from the banking and finance and insurance industries. Six companies (11.6\%) came from the manufacturing industry and four companies $(7 \%)$ were from marketing firms. Only two companies $(4.6 \%)$ of the respondents came from the oil and gas industry, which is the mainstay of industries in Nigeria. The average work experience with the companies is 4.7 years and most of them report their job titles as either CSR coordinator or CSR manager. Only five of the respondents report directly to the managing director (chief executive officer) of the company. The gender mix of the respondents was about $70 \%$ female. 
Table 2 Industry profile of respondents

\begin{tabular}{lcc}
\hline Industry & No. of respondents & Percent \\
\hline Telecommunication & 12 & $23.26 \%$ \\
Food and beverage & 5 & $9.30 \%$ \\
Manufacturing & 6 & $11.63 \%$ \\
Banking and finance & 9 & $16.28 \%$ \\
Insurance and assurance & 9 & $16.28 \%$ \\
Marketing/sales & 4 & $6.98 \%$ \\
Publishing & 2 & $4.65 \%$ \\
Consulting & 2 & $4.65 \%$ \\
Oil and gas & 2 & $4.65 \%$ \\
Other & 1 & $2.33 \%$ \\
\hline Total & 53 & $100.00 \%$ \\
\hline
\end{tabular}

\subsection{Analysis of results}

This study investigates the perception of CSR among Nigerian CSR managers by assessing the rankings of CSR dimensions as proposed by Carroll (1991). Similar studies conducted in the West corroborate the pyramid of CSR. The CSR pyramid states that the economic dimension is the most important and followed by legal, ethical and philanthropic. In each of the studies, the mean score was used to measure level of importance. However, no such studies have been conducted in SSA region. This study found some distinct differences in the order in which CSR managers in Nigeria ranked the CSR dimensions. There was a strong agreement that the economic dimension is at the foundation of all CSR strategies. A company that cannot meet its shareholders' expectations may not be able to sustain any CSR initiative. Economic sustainability should be a pre-condition for any successful CSR implementation. However the order of the remaining three dimensions differ from the way Western stakeholder view and perceive the CSR dimensions when compared to views held by CSR managers in Nigeria.

Table 3 shows zero-order correlations among the four CSR dimensions and the Cronbach alpha coefficients on the diagonal cells. Reliability assessments were made using Cronbach's reliability coefficients. After the deletion of items that do not represent the constructs being assessed, the economic, legal, ethical, and philanthropic constructs produced Cronbach's alpha values of $0.657,0.726,0.645$, and 0.811 respectively. These alpha values exceeded the suggested threshold value of 0.60 for exploratory research (Nunnally, 1978). Furthermore, the mean scores of the constructs confirms the presence of four distinct CRS components as reported by Carroll (1991). There is strong and significant correlation between the legal and ethical components suggesting that companies that adhere to strong ethical standards are more likely to have strong legal standards as well. There is also a strong and significant relationship between the philanthropic and the ethical dimensions. This goes to corroborate that philanthropy aligns well with strong ethical standards. Lastly, there appears to be a positive and significant relationship between the economic and the philanthropic dimensions, supporting the notion that philanthropy cannot be divorced from the economic realities of the firm. 
Table 3 Correlation matrix and Cronbach alpha (diagonal)

\begin{tabular}{lcccc}
\hline CSR dimension & Economic & Legal & Ethical & Philanthropic \\
\hline Economic & $\mathbf{0 . 6 4 5}$ & & & \\
Legal & -0.108 & $\mathbf{0 . 7 2 6}$ & & \\
Ethical & -0.178 & $0.539^{* *}$ & $\mathbf{0 . 6 5 7}$ & \\
Philanthropic & $0.265^{*}$ & $0.252^{*}$ & $0.508^{* *}$ & $\mathbf{0 . 8 1 1}$ \\
\hline
\end{tabular}

Notes: *Correlation is significant at the $\mathrm{p}<0.05$ level (two-tailed).

**Correlation is significant at the $\mathrm{p}<0.01$ level (two-tailed).

Diagonals are Cronbach alphas.

The relative values or weights of each of the dimensions, as implicitly depicted by Carroll, approximated the relative degree of importance that the 53 CSR managers placed on the four dimensions. Table 4 shows that the Nigeria CSR managers ranked the economic dimension as the most important dimension, followed by the philanthropic, legal, and ethical dimensions. This shows that there is a clear difference between the four identified dimensions. The difference in the magnitude of the scale is due to the fact that the previous studies used the ipsative (forced-choice) scale, while the current study used the normative Likert scale for its ease of use. The impact of socially desirable responding is commonly documented as the overall inflation of scores on normative measure (Bowen et al., 2002). A meta-analysis showed that average inflation is about half of the standard deviation of the scores (Viswesvaran and Ones, 1999). The inflation of the means is confirmed when one compares the mean scores in Table 1 to those obtained from the current study. A graphical depiction of the ranking is presented in Figure 1. The results confirm Hypothesis \#1, that the general perception of CSR in Nigeria is viewed from the lens of philanthropy. Furthermore, the results prove the research Hypothesis \#2 that although the study confirms the presence of four distinct CSR components, the hierarchical progression of the four CSR components as viewed by Nigerian CSR managers does not conform in its entirety to the Carroll's (1991) CSR pyramid. The results show that the CSR component progression in Nigeria started with the economic dimension, followed by the philanthropic dimension and then concludes with the legal and the ethical dimensions. This supports the propositions espoused in both Hypothesis $\# 1$ and \#2 and corroborates the exploratory findings of Visser (2006).

Table 4 Mean and std. dev. of the four CSR dimensions

\begin{tabular}{lccc}
\hline Dimension & Mean score & Std. dev. & Ranking \\
\hline Economic & 3.659 & 0.525 & 1 \\
Philanthropic & 3.327 & 0.618 & 2 \\
Legal & 3.008 & 0.606 & 3 \\
Ethical & 2.692 & 0.633 & 4 \\
\hline
\end{tabular}

With the exception of the economic dimension, the ranking of CSR dimensions by the Nigerian CSR managers appeared to be different from the original Carroll's conceptualisation of CSR. The economic dimension perceived as the most important by the respondents was consistent with the Carroll's framework. Therefore, it seems as though Nigerian managers understand that first and foremost, companies have to maintain sound financial strength in order ensure their survival in the market and uphold their fiscal responsibility to their shareholders. 
Figure 1 Box plot of the CSR four components

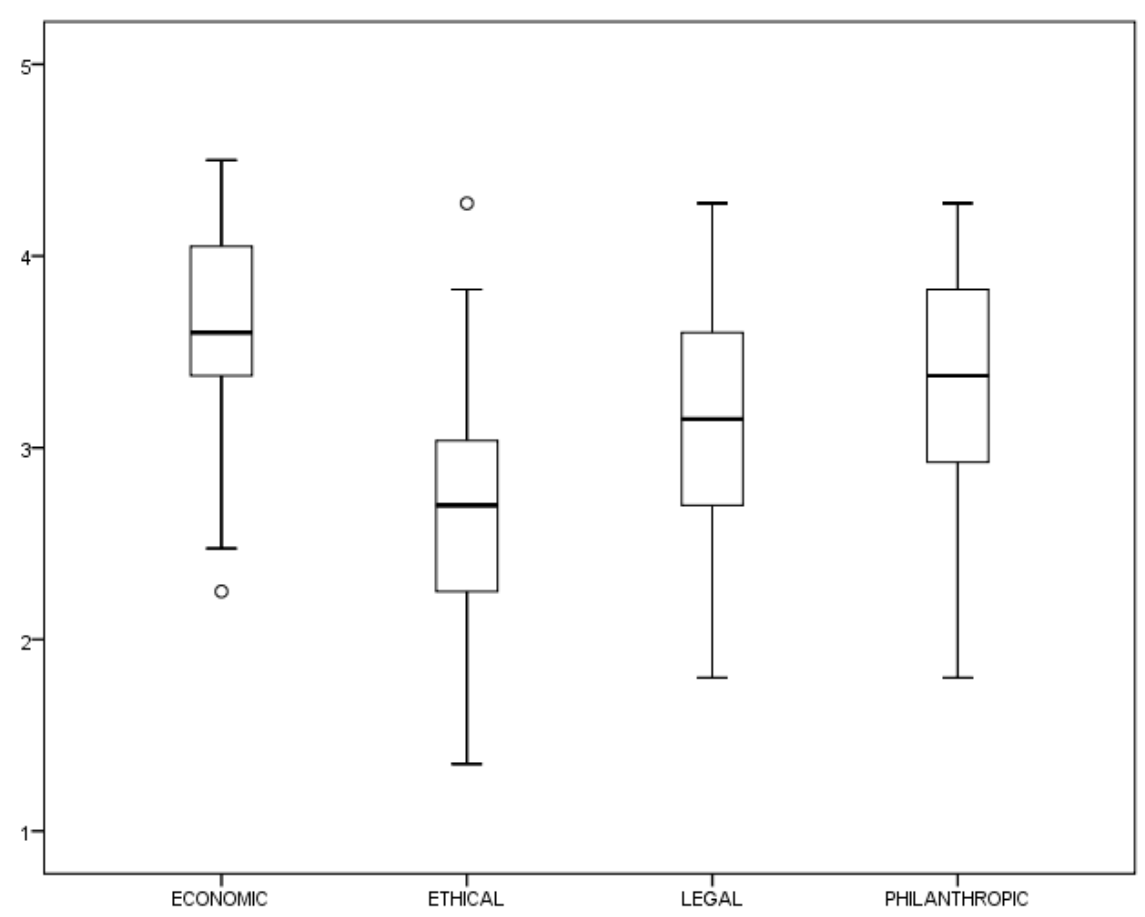

The mean test of the relative weights and ranking of the dimensions was followed by a paired sample-t-test. The resulting six pairwise comparison sample t-test shows whether there is a significant difference in the mean allocated for each pair of CSR dimensions. Based on the findings presented in Table 5, with the exception of the legal versus ethical dimensions, each pair appeared to be significantly different. This test supports the notion that the weightings of the four CSR dimensions are different and that Nigerian CSR managers viewed the CSR dimensions as not being equally weighted. This confirms the presence of the four distinct CSR dimensions as articulated by Carroll (1991). Furthermore, the economic dimension showed the greatest discriminating tendencies compared to the other three dimensions as it shows a stronger difference compared to other paired comparisons.

Table 5 Pairwise comparison (t-test) for grand mean of the four CSR dimensions

\begin{tabular}{lcc}
\hline Comparison & T-value & Prob. $>T$ \\
\hline Economic vs. legal & 7.662 & $0.000^{*}$ \\
Economic vs. ethical & 5.413 & $0.000^{*}$ \\
Economic vs. philanthropic & 3.428 & $0.001^{*}$ \\
Legal vs. ethical & -2.095 & 0.059 \\
Legal vs. philanthropic & -4.332 & $0.000^{*}$ \\
Ethical vs. philanthropic & -2.324 & $0.032^{*}$
\end{tabular}

Note: *Pairwise comparison significantly different at 0.05 level. 


\section{Discussion and conclusions}

Knowledge and best practice of CSR is still under-developed in most developing economies, especially for countries in SSA. Strategic approach toward CSR still remains in infancy in Africa, and despite the polarisation on the definition and implementation of CSR, there is a general agreement that the private sector remains one of the best institutions to make positive and significant contributions towards improving social, economic and environmental conditions in Africa. The role of corporations in improving both the governing structure and the economic potentials of the less developed economies continues to take centre stage in public discourse. This paper provides evidence that CSR is seen as important and relevant from the view of Nigerian CSR managers. The study confirms the prominence of the economic dimension. This is reiterated by the CEO of Unilever Nigeria Plc that "as funding for our CSR activities increases, it is imperative that we remain committed to the financial strength of the company to meet the expectations of our shareholders and our communities which include our employees, customers, and consumers" (Boedinger, 2009). Only when firms are able to pursue CSR activities with the support of their stakeholders can there be a market for virtue and a business case for CSR (Carroll and Shabana, 2010). However, the economic dimension was followed by the philanthropic dimension contrary to the Carroll's typology. Whereas Nigerian CSR practitioners value the importance of economic sustainability upon which to build any CSR program, they also perceived that a company must equally be engaged in the well-being of the community which they serve and upon which to build their survival in the global marketplace. Also important is fact that the company should abide by the letter of the law and maintain a high ethical standard. Corporations need to act in their own self-interest because there are enormous market potentials to be gained by entering markets in most developing countries. It has been posited that future market growths will come from emerging and developing countries.

This paper tests empirically the applicability of Carroll's CSR four-component model and its relevance in the African context. Carroll's CSR Pyramid is probably the most well-known model of CSR, with its four levels indicating the relative importance of economic, legal, ethical and philanthropic responsibilities respectively. Although all four components of CSR hold relevance in the African context, the results found that the hierarchy of the components is somewhat different from the Carroll's framework. The results empirically validate Visser (2006) revised CSR hierarchy that the economic responsibilities of companies in Africa should be at the core of their CSR priorities, followed by philanthropic, legal and ethical responsibilities therefore supporting the proposition that the relative priorities of CSR in Africa are different from the classic western ordering. Furthermore the study confirms the position that CSR implementation in Nigeria is viewed through the lens of philanthropy. The findings supports the significance of socio-cultural factors in CSR practice in Africa and confirm the importance corporate philanthropy plays in understanding and implementing CSR in Nigeria in particular, and SSA in general. The implication of these results is that as more companies in SSA embrace CSR as part of the strategic debate, more attention and support should be given to the philanthropic functions that address the pressing economic and social-cultural needs of their secondary stakeholders. These functions should assume a strategic role rather than a tactical perspective. The results of the study will help advance the dialogue of CSR implementation in developing countries. 
The use of a normative five-point Likert scale in this study raises the problem of social desirability bias because the description and presentation of the items make it easy for respondents to see through the intention of the question (Rosse et al., 1998). The leads to inflated scores of the CSR components although the relative weights are unaffected. Future studies should adopt the ipsative (forced-choice) scale after the respondents are given proper instructions on how to complete the questionnaires to avoid the problem of social desirability bias of the respondents. Furthermore, we used a captive and convenience sample to conduct this study due to the difficulty in conducting empirical research in third world countries. Therefore, the findings of the study should be generalised with caution. Conducting a future study with a different group of CSR managers and obtaining similar results would add weight to the general validity of the findings (Smith, 1983). Lastly, future research might consider qualitative studies (case research) to enrich the understanding of the hypothesised relationships, and when possible provide theoretical extension to this body of knowledge.

\section{Limitations}

Certain limitations exist which pose exciting opportunities for future research. Considering that CSR practices in Nigeria is currently at its infancy stage, the present study is conducted using a convenient sample of 53 CSR managers. The respondents are all located in Lagos, the commercial hub of Nigeria. With the convenient sample, it is appropriate that the results be generalised with caution. As the CSR practices in Nigeria grows, future research should consider taking a random and cross-sectional sample of respondents for greater generalisability. The study did not evaluate company performance among firms that completed the survey. To add to the debate on CSR-Performance nexus, future research should attempt to evaluate the relationship between CSR practices and business performance in general.

\section{Acknowledgements}

The author is grateful to the two anonymous reviewers whose comments on the earlier version of the paper greatly improved the quality of the paper.

\section{References}

Amaeshi, K., Adi, B., Ogbechie, C. and Amao, O. (2007) 'Corporate social responsibility (CSR) in Nigeria: Western Mimcry or Indigenous practices?', Lagos Organization Review, Vol. 4, No. 7, pp.1-18.

Angelidis, J. and Ibrahim, N. (2004) 'An exploratory study of the impact of degree of religiousness upon an individual's corporate social responsiveness orientation', Journal of Business Ethics, Vol. 51, No. 2, pp.119-128.

Aupperle, K.E. (1984) 'An empirical measure of corporate social orientation', Research in Corporate Social Performance and Policy, Vol. 6, pp.27-54.

Aupperle, K.E., Carroll, A.B. and Hatfield, J.D. (1985) 'An empirical examination of the relationship between corporate social responsibility and profitability', Academic of Management Journal, Vol. 28, No. 2, pp.446-463. 
Boedinger, T. (2009) 'CSR is at the top of our agenda', Nigerian Social Enterprise Report, Vol. 3, pp.59-63, TruContact Ltd.

Boele, R., Fabig, H. and Wheeler, D. (2001) 'Shell, Nigeria and the Ogoni. A study in unsustainable development: II. Corporate social responsibility and 'stakeholder management' versus a rights-based approach to sustainable development', Sustainable Development, Vol. 9, No. 3, pp.121-135.

Bowen, C.C., Martin, B.A. and Hunt, S.T. (2002) 'A comparison of ipsative and normative approaches for ability to control faking in personality questionnaires', The International Journal of Organizational Analysis, Vol. 10, No. 3, pp.240-259.

Bowman, E. and Haire, M. (1975) 'A strategic posture toward corporate social responsibility', California Management Review, Winter, pp.49-58.

Burton, B.K., Farh, J. and Hegarty, H. (2000) 'A cross-cultural comparison of corporate social responsibility', Teaching Business Ethics, Vol. 4, No. 2, pp.151-167.

Campbell, J.L. (2007) 'Why would corporations behave in socially responsible ways? An institutional theory of corporate social responsibility', The Academy of Management Review, Vol. 32, No. 3, pp.946-967.

Carroll, A. (1991) 'The pyramid of corporate social responsibility: toward the moral management of organizational stakeholders', Business Horizon, July-August, Vol. 34, pp.39-43.

Carroll, A. (1999) 'Corporate social responsibility - evolution of a definitional construct', Business and Society, Vol. 38, No. 3, pp.268-295.

Carroll, A.B. and Shabana, K.M. (2010) 'The business case for corporate social responsibility: a review of concepts, research, and practice', International Journal of Management Review, Vol. 12, No. 1, pp.85-195.

Clarkson, M.B. (1995) 'A stakeholder framework for analyzing and evaluating corporate social performance', Academy of Management Review, Vol. 20, No. 1, pp.92-117.

Crane, A., Matten, D. and Spence, L. (2008) Corporate Social Responsibility: Readings and Cases in a Global Context, Routledge Taylor \& Francis Group, London.

Daniels, T.L. (2012) 'Decision making in Eurocentric and Afrocentric organizations', Journal of Black Studies, Vol. 43, No. 3, pp.327-335.

Dartey-Baah, K. and Amponsah-Tawiah, K. (2011) 'Exploring the limits of western corporate social responsibility: theories in Africa', International Journal of Business and Social Science, Vol. 2, No. 18, pp.126-137.

Davis, K. (1973) 'The case for and against business assumption of social responsibilities', Academy of Management Journal, Vol. 16, No. 2, pp.312-322.

Driver, C. and Thompson, G. (2002) 'Corporate governance and democracy: the stakeholder debate revisited', Journal of Management and Governance, Vol. 6, No. 2, pp.111-130.

Dusuki, A.W. and Yusof, T.F. (2008) 'The pyramid of corporate social responsibility model: empirical evidence from Malaysian stakeholders' perspective', Malaysian Accounting Review, Vol. 7, No. 20, pp.1-26.

Edmondson, V.C. and Carroll, A.B. (1999) 'Giving back: an examination of the philanthropic motivations, orientations and activities of large black-owned businesses', Journal of Business Ethics, Vol. 19, No. 2, pp.171-179.

Egbas, K. (2009) 'Corporate social responsibility practice and documentation in Nigeria', Nigerian Social Enterprise Report, Vol. 3, pp.16-19.

Fashola, B. (2011) 'Fashola signs Lagos tenancy bill, Thisday, August 25, 2011.

Freeman, R.E. (1984) Strategic Management: A Stakeholder Approach, Pitman, Marshfield, MA.

Friedman, M. (1970) 'The social responsibility of business is to increase its profit', New York Times Magazine, 13 September, pp.32-33, 122-126.

Galaskiewicz, J. (1991) 'Making corporate actors accountable: institution-building in Minneapolis-St. Paul', in Powell, W.W. and DiMaggio, P.J. (Eds.): The New Institutionalism in Organizational Analysis, pp.293-310, University of Chicago Press, Chicago. 
Garriga, E. and Mele, D. (2004) 'Corporate social responsibility theories: mapping the territory', Journal of Business Ethics, Vol. 53, Nos. 1-2, pp.51-71.

GIZ (2012) Shaping Corporate Social Responsibility in Sub-Saharan Africa: Guidance Notes from a Mapping Survey, Deutsche Gesellschaft Fur InternationaleZusammenarbeit (GIZ) GmbH.

Ibrahim, N.A. and Angelidis, J.P. (1995) 'The corporate social responsiveness orientation of board members: are there differences between inside and outside directors', Journal of Business Ethics, Vol. 14, No. 5, pp.405-140.

Ibrahim, N.A. and Parsa, F. (2005) 'Corporate social responsiveness orientation: are there differences between U.S. and French managers?', Review of Business, Vol. 26, No. 1, pp.27-33.

Ibrahim, N.A., Howard, D.P. and Angelidis, J.P. (2003) 'Board members in the service industry: an empirical examination of the relationship between corporate social responsibility orientation and directorial type', Journal of Business Ethics, Vol. 47, No. 4, pp.393-401.

Idemudia, U. (2011) 'Corporate social responsibility and developing countries: moving the critical CSR research agenda in Africa forward', Progress in Development Studies, Vol. 11, No. 1, pp.1-18.

International Monetary Fund (IMF) (2014) http://www.imf.org/external/pubs/ft/survey/so/2013/ CAR051013A.htm (accessed 21 April 2014).

Ite, U.E. (2004) 'Multinationals and corporate social responsibility in developing countries: a case study of Nigeria', Corporate Social Responsibility and Environmental Management, Vol. 11, No. 1, pp.1-11.

Kakabadse, N.K., Rozuel, C. and Lee-Davies, L. (2005) 'Corporate social responsibility and stakeholder approach: a conceptual review', International Journal of Business Governance and Ethics, Vol. 1, No. 4, pp.277-302.

Kolk, A. and Lenfant, F. (2013) 'Multinationals, CSR and partnerships in Central African conflict countries', Corporate Social Responsibility and Environmental Management, Vol. 20, No. 1, pp.43-54.

Kolk, A. and Lenfant, F. (2010) 'MNC reporting on CSR and conflict in central Africa', Journal of Business Ethics, Vol. 93, No. 2, pp.241-255.

Kraft, M.E. and Furlong, S.R. (2007) Public Policy: Politics, Analysis, and Alternatives, 2nd ed., CQ, London: Eurospan, Washington, DC.

Kusku, F. and Zarkada-Fraser, A. (2004) 'An empirical investigation of corporate citizenship in Australia and Turkey', British Journal of Management, Vol. 15, No. 1, pp.57-72.

Lehmacher, W. and Pearse, M.H. (2015) 'Beyond supply chain: empowering responsive supply chain', World Economic Forum, New York, New York.

Levitt, T. (1958) 'The danger of social responsibility', Harvard Business Review, September to October, Vol. 36, pp.41-50.

Maignan, I. (2001) 'Consumers' perceptions of corporate social responsibility: a cross-cultural comparison', Journal of Business Ethics, Vol. 30, No. 1, pp.57-72.

Maignan, L. and Ferrell, O.C. (2003) 'Nature of corporate responsibilities: perspective from American, French and German Consumers', Journal of Business Research, Vol. 56, No. 1, pp.55-67.

Marz, J.W., Powers, T.L. and Queisser, T. (2003) 'Corporate and individual influences on managers' social orientation', Journal of Business Ethics, Vol. 46, No. 1, pp.1-11.

Matten, D. and Moon, J. (2008) "'Implicit" and "explicit" CSR: a conceptual framework for a comparative understanding of corporate social responsibility', Academy of Management Review, Vol. 33, No. 2, pp.404-424.

McElhaney, K. (2008) Just Good Business: The Strategic Guide to Aligning Corporate Responsibility and Brand, Berret-Koehler Publishers, San Francisco, USA.

Mintzberg, H. (1983) Power in and Around Organizations, Prentice-Hall, Englewood Cliffs, N.J. 
Mitchell, R.K., Agle, B.R. and Wood, D.J. (1997) 'Toward a theory of stakeholder identification and salience: defining the principle of who and what really counts', Academy of Management Review, Vol. 22, No. 4, pp.853-886.

Moan, F., Lindgreen, A. and Swaen, V. (2009) 'Designing and implementing corporate social responsibility: an integrative framework grounded in theory and practice', Journal of Business Ethics, Vol. 87, No. 1, pp.71-89.

Nunnally, J.C. (1978) Psychometric Theory, 2nd ed., McGraw-Hill, New York.

Oku, A., Egbas, K, Chidi I, Sylvester, J. and Tiemoko, R. (2009) 'Stakeholder expectation of CSR in Nigeria: findings from an exploratory study', Nigerian Social Enterprise Report, Vol. 3, pp.134-144.

Olokode, T. (2008) 'Corporate social responsibility: a broader view', Nigeria Social Enterprise Report, Vol. 4, No. 2, pp.32-35.

Peterson, D.K. (2004) 'The relationship between perceptions of corporate citizenship and organizational commitment', Business and Society, Vol. 43, No. 3, pp.296-319.

Pinkston, T.S. and Carroll, A.B. (1996) 'A retrospective examination of CSR orientations: have they changed?', Journal of Business Ethics, Vol. 15, No. 20, pp.199-207.

Pirsch, J., Gupta, S. and Grau, S.L. (2007) 'A framework for understanding corporate social responsibility programs as a continuum: an exploratory study', Journal of Business Ethics, Vol. 70, No. 2, pp.125-140.

Porter, M.E. and Kramer, M.R. (2011) 'The big idea: creating shared value', Harvard Business Review, Vol. 89, Nos. 1/2, pp.62-77.

Post, J.E., Fredrick, W.C., Lawrence, A.T. and Weber, J. (1996) Business and Society.Corporate Strategy, Public Policy and Ethics, McGraw-Hill Company, New York.

Prahalad, C.K. and Hammond, A. (2002) 'Serving the world's poor, profitably', Harvard Business Review, Vol. 80, No. 9, pp.48-59.

Quazi, A.M. and O'Brien, D. (2000) 'An empirical test of cross-national model of corporate social responsibility', Journal of Business Ethics, Vol. 25, No. 1, pp.33-51.

Rosse, J.G., Stecher, M.D., Miller, J.L. and Levin, R.A. (1998) 'The impact of response distortion on pre-employment personality testing and hiring decisions', Journal of Applied Psychology, Vol. 83, No. 4, pp.634-644.

Smith, T.M. (1983) 'On the validity of inferences from non-random samples', Journal of the Royal Statistical Society, Vol. 146, No. 4, pp.394-403.

Smith, W.J., Wokutch, R.E., Harrington, K.V. and Dennis, B.S. (2004) 'Organizational attractiveness and corporate social orientation: do our values influence our preference for affirmative action and managing diversity?', Business and Society, Vol. 43, No. 1, pp.69-96.

Smith, W.J., Wokutch, R.E., Harrington, K.V. and Dennis, B.S. (2001) 'An examination of the influence of diversity and stakeholder role on corporate social orientation', Business and Society, Vol. 40, No. 3, pp.266-294.

Tan, G. and Komaran, R. (2006) 'Perception of corporate social responsibility: an empirical study in Singapore', Paper presented at the Thirteenth Annual International Conference on Advances in Management, 26 June 2006.

The Economist (2014) Nigeria: Africa's New Number One [online] http://www.economist.com/ news/leaders/21600685-nigerias-suddenly-supersized-economy-indeed-wonder-so-are-its-stillhuge (accessed 3 February 2015).

Transparency International (2014) Corruption Perception Index, Transparency International: A Global Coalition against Corruption, Berlin, Germany.

Travis, L.S. (1982) 'Multinational corporate social responsibility for Third World development', Review of Social Economy, Vol. 40, No. 3, pp.427-437.

Visser, W. (2006) 'Revisiting Carroll's CSR pyramid: an African perspective', in Pedersen, E. and Hunicle, M. (Eds.): Corporate Citizenship in a Developing Countries, pp.29-56, Copenhagen Business School Press, Denmark. 
Viswesvaran, C. and Ones, D.S. (1999) 'Meta-analysis of fakability estimates: implications for personality measurements', Educational Psychological Measurement, Vol. 59, No. 2, pp.197-210.

Vlachos, P.A. (2010) 'Predictors and outcomes of corporate social responsibility: a research framework', International Journal of Business Governance and Ethics, Vol. 5, No. 4, pp.343-359.

Waddock, S.A. and Graves, S.B. (1997) 'The corporate social performance-financial performance link’, Strategic Management Journal, Vol. 18, No. 4, pp.303-319.

Warfield-Coppock, N. (1995) 'Toward a theory from an Afrocentric perspective', Journal of Black Studies, Vol. 21, No. 2, pp.30-48.

WBCSD (2005) Business for Development: Business Solutions in Support of the Millennium Development Goals, World Business Council for Sustainable Development, Geneva.

Wheeler, D., Fabig, H. and Boele, R. (2002) 'Paradoxes and dilemmas for stakeholder responsive firms in the extractive sector: lesson from the case of Shell and the Ogoni', Journal of Business Ethics, Vol. 39, No. 3, pp.297-318.

World Bank (2014) [online] http://data.worldbank.org/region/SSA (accessed 25 April 2014).

Zafar, A. (2007) 'The growing relationship between China and sub-Saharan Africa: macroeconomics, trade, investment and aid link', The World Bank Research Observer, Vol. 22, No. 1, pp.103-130.

\section{Appendix}

\section{Questionnaire items}

- Economic responsibility

1 The primary goal of companies is to make as much profit as possible.

2 Socially responsible companies strive to lower their operational costs.

3 Companies should strive for the highest returns to their shareholders.

4 Companies should not be distracted from their economic functions by solving social problems.

5 Companies should pursue those opportunities which will enhance earnings per share.

6 Corporate citizen should be defined as being as profitable as possible.

7 Meeting the profitability goal should a useful measure of corporate performance.

8 It is important to allocate resources on company's ability to improve long-term profitability.

- Legal responsibility

1 Well run companies strive to comply with all the state laws and regulations.

2 Companies must operate strictly within the legal framework of the society.

3 It is sometime expedient for companies to violate some laws and regulations.

4 Companies have to adhere to all state rules and regulations even though it may be costly for them.

5 It is important that contract safety violations are not ignored in order to complete or expedite a project. 
6 Compliance with the law shall be viewed as a useful measure of corporate performance.

7 Companies should provide good and services which at least meet minimal legal requirements.

8 Companies should strive to fulfil all corporate tax obligations.

- Ethical responsibility

1 Companies should not compromise ethical norms of the society in order to achieve corporate goals.

2 Socially responsible companies always do what is right, fair and just.

3 Companies should avoid doing harm at all cost.

4 It is important to perform in manner consistent with expectations of societal mores and ethical norms.

5 It is important to recognise that the ends do not always justify the means.

6 When securing new business, promises are not made which are not intended to be fulfilled.

7 Compliance with norms, mores, and unwritten laws of society should be viewed as a useful measure of corporate performance.

8 'Whistle blowing' should not be discouraged at any corporate level.

- Philanthropic responsibility

1 Companies should contribute resources to the community.

2 Socially responsible companies strive to provide for community betterment.

3 Companies should actively promote volunteerism and charitable activities within the local communities.

4 Companies have to commit resources to support culture and arts.

5 It is important to monitor new opportunities which will enhance company's ability to help solve social problems.

6 It is important to provide assistance to private and public institutions.

7 Philanthropic activities should be viewed as a useful measure of corporate performance.

8 It is important to assist voluntarily those projects which enhances a community's 'quality of life'. 